\title{
Mostar u svjetlu znanstvenoga interesa starokršćanske arheologije
}

IVANKA RIBAREVIĆC-NIKOLIĆ

Montréal

E-pošta: ivanka_rn@outlook.com
UDK: 904:726(497.6 Mostar)"652"

Pregledni rad

Primljeno: 4. veljače 2019.

Prihvaćeno: 21. svibnja 2019.

\section{Sažetak}

Ukazano je na stanje istraženosti i očuvanosti sedam do sada poznatih starokršćanskih lokaliteta na području današnje Općine Mostar. Pozornost je dana kasnoantičkim reljefima koji su ugrađeni kao spoliji u zidanu konstrukciju izvora Vrelo Vrba u Donjim Gnojnicama, a koji nesumnjivo ukazuju na postojanje važnoga arheološkog lokaliteta na ovome prostoru. Pod simboličkim naslovom arheološki manifesto istaknuta je važnost arheoloških lokaliteta općenito, isticanjem njihova značenja u suvremenome društvu.

Ključne riječi: starokršćanska arheologija; Mostar; spolij; Donje Gnojnice; arheološki manifesto. 
Ivanka Ribarević-Nikolić - Mostar u svjetlu znanstvenoga interesa...

\section{Uvod: potvrđeni i pretpostavljeni starokršćanski lokaliteti na širem području Mostara}

Ovim sažetim osvrtom ukazujemo na do sada poznate ili pretpostavljene starokršćanske lokalitete na području okolice grada koja je danas administrativno poistovjećena s prostorom Općine Mostar. Poziciju ovih lokaliteta, odnosno njihov zemljopisni položaj, preciziramo u odnosu na rijeku Neretvu i u odnosu na urbani prostor grada, što je lokalitet Crkvine, Cim, te njegov južni dio Bišće polje i njegov sjeverni dio Bijelo polje.

Danas je, prema publiciranim stručnim izvješćima, na području Mostara registrirano sedam položaja na kojima je potvrđeno ili pretpostavljeno postojanje starokršćanskih objekata. To su položaji: Cim u gradu, te u sjevernom dijelu grada Sutina, i nešto dalje Potoci, Humilišani i Kuti u Bijelom polju dok su južno od grada Žitomislići i Blagaj. Mi ovim osvrtom ukazujemo na osmi položaj u Donjim Gnojnicama, također u južnom dijelu, u Bišću polju, koje pripada području Mostara. Ovome lokalitetu posvećujemo znatno više pozornosti želeći istaknuti njegovu važnost i hipotetski ukazati na mogućnost postojanja starokršćanskoga horizonta.

\section{Lokalitet Vrelo Vrba u Donjim Gnojnicama kod Mostara}

Lokalitet Vrelo Vrba registriran je 1891. godine, nije arheološki istražen i okvirno je datiran u period od 1. do 4. stoljeća. ${ }^{1}$ Ovo je područje obišao Vaclav Radimsky, ukazujući na mnogobrojne ulomke rimske opeke i rimskih keramičkih oblika, primjetne uz tadašnji kolski put i osobito oko džamije, a prema usmenoj informaciji, nađeni su i rimskodobni grobovi. Naglašeno je da je sam izvor, Vrelo Vrba, kojim je objedinjeno nekoliko izvora, ozidano "ulomcima od rimskih spomenika s reljefima".2 Također, kao sporadični nalaz, publicirana je

1 Arheološki leksikon Bosne i Hercegovine, 3, Sarajevo, 1988., bilj. 24.64., str. 293, dalje u tekstu: ALBH.

2 Vaclav Radimsky, "Bišće polje kod Mostara", u: Glasnik Zemaljskog muzeja, 3, 1891., knjiga 2, str. 183. Upravo ovim reljefima dajemo pozornost dalje u članku. Napominjemo da su reljefni spoliji korišteni kao dekorativni i konstruktivni elementi specifične arhitekture ovoga izvora. Svojevremeno objekt je registriran u nadležnome, tadašnjem Regionalnom zavodu za zaštitu spomenika kulture i prirode u Mostaru. 
kasnoantička fibula koja se, prema tipičnoj morfologiji fibula s povijenom nogom, datira u peto na šesto stoljeće. ${ }^{3}$

Kasnoantički spoliji ugrađeni su u ziđe ovoga ograđenog izvora, poznatog pod imenom Vrelo Vrba. Ozidani izvor smješten je na relativno strmom, kaskadno oblikovanu zemljištu, na prostranoj zaravni (Sl. 1). Nešto niže, ispod razine platoa izvora, nalazi se velika, vjerojatno betonska, cisterna. U neposrednoj blizini, sjeverno od izvora, primjećuju se manji platoi s podzidama, koji prate konfiguraciju terena, a obrasli su travom.

Pročelje nosi jednostavne stilske odlike islamske arhitekture s tipičnim oblikom lukova tri dekorativne arkade. S obje strane ovoga niza arkada nalazi se po jedna mala niša. Vrhovi lukova arkada i bočnih niša u istoj su razini, što fasadi ove gradnje daje svojevrsni ritam. Istovremeno, prema vizualnoj procjeni, širine bočnih niša kao i njihove visine u odnosu na širinu i visinu arkada u proporcionalnom su omjeru jedan prema dva. Ovaj omjer nadasve akcentira simetriju pročelja, gdje je osa simetrije cjelovitoga pročelja istovjetna osi simetrije središnje arkade. Svi navedeni elementi doprinos su nesumnjivoj estetskoj vrijednosti ovoga specifičnog objekta. Čitavom širinom arkada postavljeni su kameni pravokutni bazeni za vodu. Svaka je od arkada imala "izvor" tekuće vode.

Kameni blokovi korišteni za gradnju različitih su dimenzija. Ujednačenost veličine kamenih ploča primjećuje se u gornjem završnom nizu ispod jednostavnoga i djelomice profiliranog "vijenca" koji je u razini kaskadnoga terena. Taj teren ujedno natkriva arhitektonsku konstrukciju izvora. Budući da je ovaj prostor prekriven vegetacijom, nije moguće zaključiti je li arhitektonska konstrukcija nad izvorom svodna ili stropna.

Reljefi su vidljivi na dvije ploče, na desnoj strani pročelja. Jedna od ploča je horizontalno pozicionirana, veći je dio reljefne dekoracije vidljiv i na žalost nije dobro očuvan. Druga je, čini se, rezana da bi se uklopila u zadane dimenzije objekta. Motiv stiliziranih grana vinove loze, listova i grozdova grožđa, čine kompoziciju plitkoga reljefa (Sl. 2).

Jesu li ostale ploče, koje su istih dimenzija kao i dekorirana ploča, također reljefno ukrašene, ne znamo. Potrebno je provjeriti postoje li

3 Adnan Busuladžıć, Morfologija antičkih fibula iz zbirke Zemaljskog muzeja Bosne i Hercegovine, Zemaljski muzej Bosne i Hercegovine, Sarajevo, 2010., str. 113, 229 inv. br. 398. 
Ivanka Ribarević-Nikolić - Mostar u svjetlu znanstvenoga interesa...

reljefi na površinama koje danas nisu vidljive jer su okrenute $\mathrm{k}$ unutarnjoj strani zida. Primjećuje se da nedostaje jedna od ploča koja je bila u lijevom dijelu pročelja. ${ }^{4}$

Zid južne strane vrela također sadrži spolije, ali znatno manjih dimenzija (Sl. 3a, 3b). Vidljive reljefne površine i općenito ostali korišteni kamen, pokazuju neujednačenost oblika bez pravilnosti u slijedu zidanja. Debeli sloj cementnoga veziva vidljiv je na površini zida (Sl. 3a). Ovaj sloj, neprimjereno velikih površina s nepravilnim fugama koje su istaknute urezanim linijama, a ne logičkim konstruktivnim spojevima, većim dijelom prekriva kamen, te je teško sagledati realne dimenzije spolija. Reljefne površine vidljive su u segmentima. Danas možemo prepoznati reljef $s$ vegetacijskim motivom stiliziranih grana, s vidljivim segmentom grozda grožđa, sličan onome prikazanom na reljefnoj ploči pročelja. Listovi vinove loze nisu vidljivi. Primjetno je da se radi o ulomku koji ima dekorirani vijenac. Ne možemo pouzdano zaključiti jesu li djelomice vidljivi grozdovi grožđa fizički dio ovoga spolija ili je to samostalni ulomak (Sl. 3a).

Tijekom obilaska ovoga lokaliteta 1990. godine bila je vidljiva znatno veća površina reljefnih spolija, okružena tada korištenim vezivom $s$ vapnom (Sl. 3b). Jasno je da su u pitanju dva ulomka reljefne obrade. Jedan nosi motiv vinove loze i grozdova i stilski je identičan motivima koje vidimo na pločama pročelja. Ulomak koji ima profilirani vijenac dekoriran je specifičnim motivom stilizirane akantusove lozice kojega uobičajeno nazivamo virovita rozeta (usporediti slike 3a i 3b). Motiv virovite rozete susrećemo na starokršćanskim reljefima crkve u Žitomislićima, također u južnome dijelu grada. Isti motiv virovitih rozeta $\mathrm{u}$ kombinaciji s drugim motivima dio je dekoracije reljefne ploče koja pripada starokršćanskome kamenom crkvenom namještaju iz Potoka u sjevernom dijelu Mostara (Sl. 9). Ovaj spolij, reljef $s$ motivom virovite rozete, kojega danas ne možemo jasno vidjeti, doprinos je hipotezi o postojanju starokršćanskoga sakralnog objekta u Donjim Gnojnicama.

Veća površina pročelja, uključujući i reljefne spolije, podjednako kao i pojedine površine bočnoga zida, obojene su plavozelenom, plavom i žutom bojom. Nesumnjivo, taj bojeni sloj je recentni, vjerujemo ne-

4 Budući da tijekom rada na ovom članku nismo uspjeli konzultirati povijesne podatke o arhitektonskom objektu izvora Vrba i aktualnoj razini njegove zaštite, informacije koje iznosimo zasnovane su isključivo na vizualnoj analizi tijekom recentnoga obilaska i fotografiranja lokaliteta 8. kolovoza 2018. 
planski i nečiji samovoljni rad, što je dodatni problem budućoj konzervaciji objekta. ${ }^{5}$

Način izradbe i odabrani motivi reljefne dekoracije ovih spolija vrlo indikativno ukazuju na moguće postojanje sakralnoga starokršćanskog objekta kojemu je ova reljefna dekoracija, vjerujemo, pripadala. Istovjetno stilizirani motivi grana vinove loze, listova i grozdova grožđa i njihova specifična kompozicija, uz već spomenuti motiv virovite rozete, susreće se na nedalekim, potvrđenim starokršćanskim lokalitetima, od kojih osobito ističemo lokalitet Crkvine u Žitomislićima. Primjetna je sličnost izražena u načinu oblikovanja lista vinove loze, načinu izradbe i načinu stilizacije grana. Svakako, treba imati na umu ograničene mogućnosti sagledavanja kompozicije i navedenih detalja reljefnih spolija Vrela Vrba, te naša opažanja zahtijevaju kritičku potvrdu zasnovanu na detaljnoj komparativnoj analizi.

Također, ne smijemo isključiti činjenicu da motiv vinove loze i grožđa nije isključivi ikonografski vokabular starokršćanske sakralne umjetnosti, nego ga srećemo i kao dekorativni reljefni motiv općenito tijekom rimskodobnoga perioda. Navodimo kao primjer sarkofage, datirane u 4. stoljeće, pronađene u Baćevićima, što je lokalitet u blizini, također na Bišću polju. ${ }^{6}$

5 Ovaj je lokalitet prvi put posjećen tijekom 1990. godine. Cilj posjeta 8. kolovoza 2018. bilo je fotografiranje, vizualni uvid i provjera prethodne osobne impresije o ovim reljefima. Nisu izvršena mjerenja objekta, niti pojedinih elemenata gradnje. Nije rađena deskriptivna analiza načina obrade površina korištena kamena, naravno u mjeri u kojoj je to danas mjerodavno i moguće uzevši u obzir djelovanje atmosferilija i dodatno sadašnjega sloja boje. Pozornost je posvećena samo reljefnim spolijima.

6 Vaclav Radimsky, "Prehistoričke i rimske starine kod Bačevića blizu Mostara", u: Glasnik Zemaljskog muzeja, 4, 1892., str. 332-336. O istim sarkofazima i mogućoj klesarskoj radionici: Đuro BASLER, Arhitektura kasnoantičkog doba u Bosni i Hercegovini, Veselin Masleša, Sarajevo, 1972., str. 146, sl. 159. Primjeri su višebrojni, a također upravo motiv vinove loze i grožđa, te pitanja stila i kontinuiteta njegove aplikacije i na starokršćanski kameni crkveni namještaj, tema je zasebnih studija. Ovakve studije i detaljne analize bit će neophodne kada se konzervatorskim zahvatom ove spolije izvade iz zidova objekta. Za više detalja o razvoju i uporabi ovoga motiva: VelJKo PAšKvaLIN, "Ostaci starokršćanske bazilike na Crkvini (Grudine) u Bugojnu s osvrtom na MVN(icipium) BIST(ue) ili BISTVES, sjedište Bistuenske biskupije i biskupa Andrije", u: Acta XIII Congressus internationalis archaeologiae christianae, III, (ACIAC, 13, 3), Citta del Vaticano - Split, 1998., str. 572, i podnožne bilj. 87-90 s pregledom bibliografije. 
Ivanka Ribarević-Nikolić - Mostar u svjetlu znanstvenoga interesa...

Jedino arheološka metoda istraživanja može dati mjerodavne podatke o postojanju i namjenskome određenju nesumnjivo značajnoga kasnoantičkog objekta ili objekata, kojima su mogli pripadati i reljefi ugrađeni kao spolije u ziđe Vrela Vrba. Kao što smo naglasili, hipotetski, ove reljefe možemo pripisati pretpostavljenom starokršćanskom sakralnom objektu, ali ne možemo isključiti i moguću njihovu drukčiju pripadnost.

Vađenje iz zidova i adekvatna konzervacija svih reljefnih ulomaka čini nam se opravdanom, sagledavajući njihovu stilsku i umjetničku vrijednost i važnost povijesne poruke koju nesumnjivo nose. ${ }^{7}$ Ujedno, želimo naglasiti neophodnost konzervatorskih zahvata i moguće djelomične rekonstrukcije gornje zone pročelja i bočnoga zida Vrela Vrba, gdje su kasnoantički reljefi, ali isto tako i bazena za vodu ovoga objekta islamske gradnje, koji ima nesumnjivu stilsko-arhitektonsku vrijednost. Također, istaknimo i povijesnu vrijednost konstruktivnoga rješenja sakupljanja vode $s$ više izvora podzemnim sustavom kanala, koji su objedinjeni današnjim Vrelom Vrba.

\section{Sedam lokaliteta na području Mostara u svjetlu znanstveno- ga interesa starokršćanske arheologije}

Stupanj znanstvene istraženosti, očuvanosti i adekvatne prezentacije do danas poznatih starokršćanskih položaja Cim, Sutina, Potoci, Humilišani, Kuti, Žitomislići, Blagaj i vjerojatno Donje Gnojnice, nije primjeren njihovoj važnosti i značenju. Tako su i naše spoznaje podjednake nezavidne razine. Starokršćanski horizont u ovome segmentu rimske provincije Dalmacije, Salonitanske metropolije, a pod jurisdikcijom Naronitanske biskupije, koji u prvoj polovici 6 . stoljeća vjerojatno postaje sijelom jedne novoosnovane biskupije, zavrjeđuje veću znanstvenu i javnu pozornost. ${ }^{8}$ Ovo je, kako se čini, najslabije arheološki istražen starokršćanski horizont na području Hercegovine.

7 Marin Barišić - Vinka Marinković, "Fenomen antičkih spolija - problem zaštite i prezentacije", u: Kulturna baština, 37, Split, 2011., str. 317-338.

8 Mnogobrojne su znanstvene studije posvećene pitanju ubikacije jedne od biskupija koja se izravno može vezati za navedeno područje Mostara, odnosno za Cim. Spomenut ćemo da su najčešća razmišljanja čvrsto bazirana na pisanim izvorima, aktima salonitanskih sabora, vezana za ubikaciju sijela biskupije Sarsenterum čiji je biskup Paulinus bio nazočan na drugom Salonitanskom saboru 533. godine, ili je to mogla biti biskupija Mactaris (ecclesia Mactarita- 
Istaknimo ponovo postojanje starokršćanskih lokaliteta, onih s vidljivim ili potvrđenim arhitektonskim ostatcima ili onih pretpostavljenih zahvaljujući nalazima starokršćanskih reljefa ili arhitektonske skulpture, potvrđeno je u Cimu, Žitomislićima, Sutini, Humilišanima i Kutima. U Potocima, Blagaju i hipotetski u Donjim Gnojnicama, nalazi arhitektonske skulpture i ulomci reljefa ukazuju na starokršćanski lokalitet, gdje arhitektonski ostatci još uvijek nisu potvrđeni arheološkom metodom istraživanja. ${ }^{9}$

Sustavnim arheološkim iskopavanjima potvrđeni su i konzervirani arhitektonski ostatci dva sakralna kompleksa, onaj u Cimu i drugi u Žitomislićima.

U Cimu (Sl. 4), na lokalitetu Crkvine, konzervirana je trikonhalna crkva s bočnim prostorijama u nizu, gdje je krstionički zdenac smješten u sjevernom aneksu. Uz crkvu je izgrađen također trikonhalni manji objekt memorije (memoria). Nedaleko, jugozapadno u odnosu na crkvu, otkriven je stambeni objekt, vjerojatno sagrađen istovremeno s crkvom. ${ }^{10}$

U Žitomislićima, na lokalitetu Crkvine (Sl. 5), konzervirana je dvojna crkva. Dvije su crkve, od kojih je sjeverna s krstioničkim zdencem, povezane zajedničkim prostorijama i ograđene zajedničkim

na) čiji se biskup Viktor spominje u istom salonitanskom dokumentu. Ovo složeno pitanje, na koje još uvijek ne postoji odgovor potvrđen materijalnim (arheološkim) nalazima, tema je, posredno dotaknuta, u gotovo svim citiranim radovima koji obrađuju starokršćanske crkve na ovome području, a koji će biti citirani dalje u tekstu. Za ovdje navedene informacije vidjeti: PAsCALE Chevalier, Salona II, L'architecture paléochrétienne de la province romaine de Dalmatie (IV-VII s.), En dehors de la capitale, Salona, Tome 1, Catalogue, Rome - Split, 1995., str. 395. Pitanje ubikacije biskupskoga sijela prelazi tematske okvire ovoga prikaza te mu stoga ne možemo posvetiti više pozornosti.

9 Zahvaljujemo napose jednomu od anonimnih recenzenata na pozornosti koja je posvećena ovome članku, a očitovana je iscrpnim osvrtom, što osobno cijenimo. Vjerujemo da smo nekolicinom opširnije predočenih informacija jasnije iskazali ovaj sažeti kronološki pregled istraživanja starokršćanskoga horizonta na području Mostara, te da smo ujedno uspjeli ukazati na važnost i značenje ovih i općenito svih arheoloških lokaliteta.

10 ALBH, 3, bilj. 24.45, str. 292-293; Tomislav AnĐElić, "Kasnoantička bazilika u Cimu kod Mostara", u: Glasnik Zemaljskog muzeja, 29, (1974.), Sarajevo, 1976., str. 179-244; PASCAle Chevalier, Salona II, L'architecture paléochrétienne de la province romaine de Dalmatie (IV-VII s.), En dehors de la capitale, Salona, Tome 1, Catalogue, Rome - Split, 1995., str. 394-400; Salona II, Tome 2, Illustrations et conclusions Pl. LIX, sl. 1,3. 
Ivanka Ribarević-Nikolić - Mostar u svjetlu znanstvenoga interesa...

zidom koji mjestimice svojom pozicijom ujedno postaje sastavni dio arhitektonskoga sakralnog korpusa. Stambeni objekt u neposrednoj blizini pripada ovome arhitektonskom sklopu. ${ }^{11}$

Crkva u Sutini (titular sv. Ivan?), (Sl. 6) arheološkom je metodom djelomice istražena. Indikativni nalazi u sjevernim prostorijama ukazali su na postojanje krstioničkoga zdenca. ${ }^{12}$ Istraživanja nisu nastavljena. Sačuvani, istraženi ostatci arhitekture, kao i cjelokupna površina arheološkoga lokaliteta, uništena je recentnom gradnjom prodajnoga centra. ${ }^{13}$

U Humilišanima, na lokalitetu Kratine, nađeni su primjerci arhitektonske skulpture među kojima imposti s urezanim motivom križa, nesumnjivo starokršćanskoga stilskog određenja (Sl. 7), te arhitektonski element kamenoga, dobro obrađena "kanala" za vodu koji završava stiliziranim motivom lavlje glave (Sl. 8). Probnim arheološkim istraživanjima potvrđeni su i arhitektonski ostatci objekta. Planirano sustavno arheološko istraživanje nije realizirano. Plan objekta nije poznat. ${ }^{14}$

U Kutima zabilježeni su ostatci arhitekture vidljivi na površini i osobito jasno čitljivi ostatci krstioničkoga zdenca starokršćanskoga sakralnog objekta. Pretpostavljen je kontinuitet korištenja ovoga mjesta u kasnom srednjem vijeku. Arheološka istraživanja nisu provedena. Plan objekta nije poznat. ${ }^{15}$

U Potocima, Grčine, poznat je lokalitet gdje su nađeni izvanredni primjerci starokršćanskih reljefa i arhitektonske skulpture, nesum-

11 ALBH, 3, bilj. 24.44, str. 292; Tomislav AnĐelić, "Kasnoantička dvojna bazilika (basilica geminata) u Žitomislićima kod Mostara", u: Glasnik Zemaljskog muzeja, 32 (1977.), Sarajevo, 1978., str. 293-330; P. Chevalier, Salona II, Catalogue, str. 415-418; Salona II, Illustrations et conclusions Pl. LXI sl. 1, 2, Pl. LXII sl. 1,2.

12 Pascale Chevalier, "Les baptistères paléochrétiennes de la province romaine de Dalmatie", u: Diadora, 10, Zadar, 1988., str. 158, na osnovi razgovora s V. Atanacković-Salčić koja je vodila istraživanja u Sutini.

13 ALBH, 3, br. 24, 42c; P. Chevalier, Salona II, Cataloque, str. 393-394; Salona II, Illustrations et conclusions Pl. LIX sl. 2; Vukosava Atanacković-SalČić, "Nove ranokršćanske crkve na području Mostara", u: Hercegovina, 3(11), Mostar, 1997., str. 23-30; O ovome lokalitetu vidjeti i podnožnu bilj. br. 21-22.

14 ALBH, 3, bilj. 24.222; P. Chevalier, Salona II, Catalogue, str. 386-387; V. AtANACKoviĆ-SALČIĆ, nav. dj., str. 26-27.

15 ALBH, 3, bilj. 24,39; P. Chevalier, Salona II, Cataloque, str. 387-388. 
njivo sakralnog objekta (Sl. 9). Pozicija objekta ili njegovi arhitektonski ostatci nisu potvrđeni probnim arheološkim iskopavanjima, te je i njegov plan ostao nepoznat. Mjesto Potoci jedno je od najvažnijih rimskodobnih lokaliteta na području Hercegovine koje nikada nije bilo sustavno istraženo. Neophodno je primijetiti da se prethodno spomenuti lokalitet u Humilišanima nalazi na samo nekoliko kilometara udaljenosti, što ukazuje na kulturološku povezanost ovih položaja i neophodnost sustavna arheološkog istraživanja. ${ }^{16}$

Napomenimo da su Cim, a zatim Sutina, Potoci, Humilišani i Kuti na položajima u neposrednoj blizini, u sjevernom dijelu Općine Mostar (Karta 1). Kako je to već naglašeno u stručnoj literaturi, treba ih promatrati kao sakralne objekte koji pripadaju jedinstvenome crkvenom upravnom središtu. Ako se prihvati identifikacija Mostara s biskupskim sjedištem Mactaris (ili Sarsenterum), tada, kako to naglašava P. Chevalier, Potoci, Kuti i Humilišani, koji su samo desetak kilometara udaljeni od grada, čine važne točke kršćanske topografije 6. stoljeća. ${ }^{17}$

Blagaj na Buni jest lokalitet u kojemu su recentnim zaštitnim arheološkim iskopavanjima potvrđeni arhitektonski ostatci maloga starokršćanskog objekta s apsidom. ${ }^{18}$ Prethodno nađeni impost kapitel (Sl. 10a, 10b), vjerujemo, ukazuje na postojanje objekta od veće važnosti i

16 ALBH, 3, bilj. 24.171, str. 298; CARl Patsch, "Rimsko glavno mjesto u Bijelom polju kod Mostara", u: Glasnik Zemaljskog muzeja, 16, Sarajevo, 1904., str. 41-42; NAdA Miletić, "Izvještaj o zaštitnom iskopavanju u Potocima kod Mostara", u: Glasnik Zemaljskog muzeja, ns, 17, Sarajevo, 1962., str. 153-157; P. Chevalier, Salona II, Catalogue, str. 388-389.

17 P. Chevalier, Salona II, Catalogue, str. 389; Isto, Karta V: Sjeveroistok Bosne i Hercegovine (Travnik - Mostar), odakle je preuzet prikazani detalj Mostara (Karta 1). Ova je ideja akcentirana u navedenim radovima V. AtanackovićSalčić osobito za mostarske navedene položaje, gdje autorica izričito naglašava važnost Sutine i Humilišana, imajući na umu da su nalazi iz Potoka već povijesno poznati u znanstvenoj literaturi kao nesumnjivo kršćansko središte. Vidjeti podnožne bilj. br. 12-13.

18 Enver Imamović, "Rezultati zaštitnog iskopavanja na lokalitetu tekija na Vrelu Bune u Blagaju kod Mostara", u: Godišnjak Centra za balkanološka ispitivanja ANUBiH, 43, Sarajevo, 2014., str. 195-216, T.5 s prikazom višeslojnih nalaza arhitektonskih objekata različitih perioda gradnje. Na sl. 10 prikazan je dio zida apside, a sl. 11 je fotografija estriha. Dimenzije maloga jednobrodnog objekta su 6,30 m x 5,70 m, širina apside je 4,5 m, a debljina zidova objekta je 0,70 m, http://www.anubih.ba/godisnjak/god43/Godisnjak43-full.pdf (15. 12. 2018.). 
Ivanka Ribarević-Nikolić - Mostar u svjetlu znanstvenoga interesa...

veličine, osobito imajući na umu važnost ovoga područja u rimskom periodu. Đuro Basler donosi crtež jednoga kapitela, ukazujući da su kilometar istočno od staroga grada otkrivena svojedobno dva imposta koji upućuju na podrijetlo s neke kasnoantičke crkvene građevine. ${ }^{19}$

Kao osmi, hipotetski, starokršćanski lokalitet, pridružujemo spomenuti položaj u Donjim Gnojnicama. Lokaliteti Donje Gnojnice, Blagaj na Buni i Žitomislići, položaji su u južnom dijelu mostarskoga okružja. Napomenimo da su Donje Gnojnice i Blagaj u neposrednoj blizini na Bišću polju.

\section{Retrospektivni osvrt na starokršćansku problematiku u kontekstu Hercegovine i Mostara u zadnjih dvadeset i pet godina}

Prije dvadeset pet godina, 1994., u prvom broju časopisa Mostariensia, kratkim tekstualnim prilogom, simbolički je obilježena stogodišnjica prvoga međunarodnoga kongresa za starokršćansku arheologiju u Saloni (CIAC XIII) i ujedno stotinu godina postojanja starokršćanske arheologije u Hercegovini. Glavninu slikovnih priloga u časopisu čine fotografije starokršćanske arhitektonske skulpture s pretpostavljenih ili arheološki potvrđenih starokršćanskih položaja. ${ }^{20}$

Fotografije, publicirane u istom časopisu, rad su Ćirila Ćire Raiča. Izabrane su među mnogobrojnim fotografijama starokršćanskih reljefa i arhitektonske skulpture iz (depoa) Muzeja Hercegovine u Mostaru i Zemaljskoga muzeja u Sarajevu. Prilog predočen ovdje, radnom skicom i fotografijom (Sl. 11a, 11b) dokumentiran je tijekom intenzivnoga rada na ovoj tematici 1990. - 1991. godine. U istom periodu obrađen je većinski dio starokršćanskih reljefa i arhitektonske skulpture hercegovačkoga područja, koji je u danom vremenu bio dio inventara istodobne zbirke navedenih institucija. Ovu informaciju spominjemo kao podsjetnik i potrebu iskazanu od velika broja

19 Đuro BAsler, Arhitektura kasnoantičkog doba u Bosni i Hercegovini, Sarajevo, 1972., str. 67, sl. 39; CARL PATsCH, "Arheološko-epigrafska istraživanja o povijesti rimske pokrajine Dalmacije", u: Glasnik Zemaljskog muzeja, 16, Sarajevo, 1904., str. 33-43.

20 Ivanka Ribarević-Nikolić, "Kronološki pregled dosadašnjih istraživanja starokršćanske arhitekture u Hercegovini", u: Mostariensia, 1, Mostar, 1994., str. 115-121, http://independent.academia.edu/IvankaRibarevic (18. 9. 2018.). 
znanstvenika koji se bave ovim područjem arheologije i umjetnosti da je neophodno pripremiti digitalni katalog arhitektonske starokršćanske skulpture s područja provincije Dalmacije. Ukazujemo na rad J. Vučića, gdje je istaknuta važnost katalogiziranja starokršćanskih reljefa i arhitektonske skulpture prvenstveno u cilju identifikacije radionica crkvenoga namještaja. Nadalje autor citira radove znanstvenika koji grupiranjem radova istovjetne ikonografske i stilske određenosti ukazuju na mogućnost definiranja teritorijalne rasprostranjenosti pojedinih biskupskih sijela, što su svakako zanimljiva razmišljanja. ${ }^{21}$ Dokumentacija spomenuta ovdje može biti prinos takvu projektu. ${ }^{22}$

Općenito vrlo prisutni znanstveni interes za starokršćansku arheologiju poticaj je za ovaj retrospektivni, teoretski osvrt čija je problematska aktualnost očitovana i četvrt stoljeća kasnije u realnom prostoru i vremenu. Spomenuti XIII. međunarodni kongres starokršćanske arheologije, Congressus internationalis archaeologiae christianae CIAC, bio je prilika za predstavljanje novih arheoloških spoznaja, kako teoretskih viđenja, tako i rezultata arheoloških istraživanja.

21 Preporučamo konzultiranje ovoga rada i u cilju sagledavanja široke problematike starokršćanskoga razdoblja i osobito iscrpne bibliografije. JAKOV VUčıć, Topografija Naronitanske biskupije, Sveučilište u Zagrebu, Filozofski fakultet, Doktorski rad, Zagreb, 2012., str. 339, 350, 351. https://independent.academia. edu/JakovVucic (2. 12. 2018.).

22 Veći dio dokumentacije, deskripcija, skice reljefnih ulomaka i arhitektonske skulpture i osobito značajna fotodokumentacija, produkt je studijskoga rada autorice u depou i na zbirkama, Muzeja Hercegovine u Mostaru i Zemaljskoga muzeja u Sarajevu, s ciljem da materijal bude obrađen kao tematska cjelina. Stjecajem okolnosti ovaj materijal nije publiciran. Navedena dokumentacija i, osobito ističemo, fotodokumentacija zajedno čine dokumentarnu osnovu, koja može biti prinos katalogizaciji jednoga dijela starokršćanskih reljefa i arhitektonske skulpture hercegovačkoga područja. Ova suradnja autorice članka i fotografa Ć. Raiča, djelatnika onodobnoga Regionalnog zavoda za zaštitu spomenika kulture i prirode u Mostaru, realizirana je uz podršku matične kuće i uz neophodnu suglasnost navedenih muzeja i njihovo dopuštenje za rad u depoima i na zbirkama i dopuštenje za fotografiranje u cilju znanstvene prezentacije, za što dugujemo osobnu zahvalnost. Recentno, 2018., Muzej Hercegovine tiskao je Katalog kamene arheološke zbirke, čiji je autor Edin Mulović, što svakako otvara put za doprinos i suradnju na idejno sličnom i nadajmo se skorom globalnom projektu katalogizacije starokršćanskih reljefa i arhitektonske skulpture s područja današnje Hercegovine, akcentirano materijala iz Cima i Žitomislića. 
Problematika starokršćanske arheologije Hercegovine, specifično sakralne arhitekture, prezentirana je s dva priopćenja, od kojih je jedno imalo uži tematski osvrt, a drugo sintetski problematski pristup. $\mathrm{Vu}-$ kosava Atanacković-Salčić predočila je priopćenje naslovljeno "New Discoveries of Early Christian Churches in the Mostar Region" kojim su obuhvaćeni arhitektonski ostatci, odnosno plan crkve iz Sutine (Sv. Ivan). Također prezentirani su arheološki nalazi koji čvrsto ukazuju na postojanje crkve u Humilišanima odakle potječu dva impost kapitela s urezanim motivom križa i dobro obrađeni "kanal" za vodu koji završava prikazom lavlje glave (Sl. 6, 7, 8). Probnim arheološkim istraživanjem potvrđeno je postojanje objekta, nesumnjivo sakralnoga određenja, kojemu pripada navedena arhitektonska skulptura. Autorica izričito naglašava da ovim novim nalazima regija Mostara dobiva značajno mjesto i zavrjeđuje posebnu pozornost u studijama starokršćanske arheologije. ${ }^{23}$ Tema drugoga priopćenja dotiče pitanje tipologije, procesa formiranja te funkcionalne uvjetovanosti složenoga tipa starokršćanskih crkava na primjerima iz Hercegovine. Arheološki potvrđeni arhitektonski ostatci crkve u Sutini obuhvaćeni su i ovim radom. ${ }^{24}$

Osobito želimo istaknuti dvije važne znanstvene studije čijim je izlaskom iz tiska dodatno obilježena obljetnica salonitanskoga kongresa, a tematski, na visokoj znanstvenoj razini, problematika starokršćanske arheologije. To su monografije Salona I i Salona II, bez kojih je danas vrlo teško imati dostatnu osnovu za razmišljanje o višesmjer-

23 Ovi su podatci preuzeti iz interno tiskanoga pregleda sudionika, odnosno naslova i predočenih sažetaka "Sažeci - Resumes" (Split - Salona, 1894. - 1994., XIII CIAC) u sekciji Priopćenja - Communications, str. 40. Ova tematika prezentirana je u zasebnoj studiji: V. Atanacković-SAlčıć, nav. dj., str. 23-30.

24 Ivanka Ribarević-Nikolić, "Genezis and Formation of a Complex Type of Church Using Early Christian Churches in Herzegovina as Example", u: Nenad CAmbi - Emilio Marin (ur.), Radovi XIII. međunarodnog kongresa za starokršćansku arheologiju, III, (ACIAC, 13,3), Citta del Vaticano - Split, 1998., str. 693-714. U navedenom radu, u podnožnoj bilješci br. 5 autorica zahvaljuje V. Atanacković-Salčić, čijom ljubaznošću je tada još nepublicirani plan crkve u Sutini mogao biti uvršten u navedeno izlaganje, koje je zapravo tematski sažetak magistarske radnje. Budući da je velik dio dokumentacije Zavoda za zaštitu spomenika kulture u Mostaru bio uništen, jedini je dostupni primjerak plana crkve u Sutini bio onaj dobiven od autorice istraživanja V. Atanacković-Salčić, te je prethodna kolegijalna ljubaznost mogla biti uzvraćena, kako bi ovaj važni starokršćanski sakralni objekt bio izvorno, autorski predstavljen na XIII. CIAC. 
noj i složenoj tematici koju neminovno dotiče starokršćanska problematika. U prvoj monografiji prezentirana je arhitektonska skulptura Salone. ${ }^{25}$ Druga je autorski rad Pascale Chevalier, izvorno doktorski rad, kojom je obuhvaćena starokršćanska arhitektura rimske provincije Dalmacije izvan njezina crkvenoga središta Salone. To nadalje znači da je ovim međunarodnim projektom, realiziranim suradnjom Arheološkoga muzeja u Splitu i École française de Rome, cjelovito obrađena do tada poznata starokršćanska arhitektura s prostora današnje Hercegovine. ${ }^{26}$

Unutar istoga djela, u zasebnom poglavlju pogovora, Emilio Marin preporuča ovaj iscrpni znanstveni rad Pascale Chevalier kao polazišnu osnovu "u svakom novom istraživanju starokršćanske arhitekture rimske provincije Dalmacije kao korektiv i kao orijentir, u pravom smislu riječi priručnik (...)." Također, kako naglašava E. Marin, istaknuta je važnost kronološkoga pitanja starokršćanske arhitekture u Dalmaciji, koja je u najvećem broju slučajeva definirana šestim stoljećem $s$ naglašenom tendencijom da se interpretira trajanje te arhitekture sve do polovice 7. stoljeća, a kao ključna godina uzima se 641., godina prijenosa relikvija u Lateran. Nadalje, važno je ukazati da je velik broj crkava obnovljen sredinom 6. stoljeća, ili čak u drugoj polovici toga stoljeća i početkom 7 . stoljeća. ${ }^{27}$

Također, govoreći o arhitektonskoj osobitosti ili tipološkom određenju, odnosno tlocrtu starokršćanskih crkava, većina autora prihvatila je terminološko određenje "složena crkva". To znači da se uz jednobrodnu crkvu s obje strane nalazi niz bočnih prostorija-aneksi.

25 Noël Duval - Emilio Marin - Catherine Metzger (ed.) Salona I. Recherches Archéologiques franco-croates à Salone. Catalogue de la sculpture architecturale paléochrétienne de Salone. Rome: École française de Rome, 1994., str. 1-100. (Publications de l'École française de Rome, 194); https://www.persee.fr/ doc/efr_0000-0000_1994_arc_194_1 (27.10.2018.).

26 P. Chevalier, Salona II, L'architecture paléochrétienne de la province romaine de Dalmatie (IV-VII s.), En dehors de la capitale, Salona, Tome 1 - Catalogue, Rome - Split, 1995., 485 str.; Tome 2. Illustrations et conclusions, 270 str., s prikazom svih poznatih tlocrta na području provincije Dalmacije. Tom 2 moguće je konzultirati elektronički: https://www.persee.fr/doc/efr_00000000_1995_arc_194_2 (13. 11. 2018.). Također autorica donosi i sažet povijesni pregled istraživanja uz bibliografski pregled na zavidnoj razini. Izvorni tekst je na francuskom, a svaka od tematskih jedinica ima sažetak na engleskom i hrvatskom jeziku.

27 Isto, str. 185, Pogovor, E. Marin. 
Ivanka Ribarević-Nikolić - Mostar u svjetlu znanstvenoga interesa...

Baptisterij je najčešće smješten u sjevernom aneksu. Također ispred jednobrodne crkve ponekad je predvorje. ${ }^{28}$

Slijedom citiranih mišljenja i iznesenih informacija ističemo vrijednost starokršćanskih spomenika na području današnje Hercegovine, kao povijesnoga dijela rimske Dalmacije, i analogno, njihovu iznimnu vrijednost u kontekstu europske povijesti starokršćanske arhitekture, arhitektonske skulpture i reljefnih dekoracija kamenoga namještaja.

Novi nalazi starokršćanskih sakralnih objekata, te revizijska istraživanja i konzervacija nezaštićenih lokaliteta, potvrđuju pozitivan stručan i znanstveni pristup starokršćanskoj arheološkoj baštini na području Hercegovine. Na žalost, isti zaključak ne možemo donijeti kada govorimo o starokršćanskim objektima ili lokalitetima na širem administrativnom području grada Mostara.

\section{Razina istraženosti i razina očuvanosti s prijedlogom smjer- nica zaštite osam spomenutih arheoloških lokaliteta na području Mostara}

Informacije koje iznosimo sažeti su pregled spoznaja o starokršćanskim lokalitetima Mostara u posljednjih četvrt stoljeća, koji je zasnovan na odabranim publiciranim radovima tematski izravno vezanim za spomenute lokalitete, znači njih sedam i hipotetski osmi na položaju u Donjim Gnojnicama. Polazišna osnova svih informacija o arheološkim lokalitetima jest Arheološki leksikon Bosne i Hercegovine, gdje nalazimo pregled svih registriranih nalazišta neovisno o razini njihove istraženosti, uz navedenu bibliografiju. Tiskan 1988. godine, ovaj leksikografski opus (Tom 1-3 i Arheološke karte 1-4), pregled je rezultata stoljetnoga rada na rekognosciranju, i istraživanju ovoga područja, što je potvrda postojanja arheologije kao neovisne i respektivne discipline na ovim prostorima. Izravno konzultirani pregled publiciranih rezultata arheoloških istraživanja glavnoga istraživača mjerodavni je izvor informacija za sve druge zaključke. Uz navedeno osvrnuli smo se na citirani sintetski rad Pascale Chevalier, kojim su predočeni planovi (hercegovačkih) crkava uz deskripci-

28 Igor Fisković je prvi predložio navedenu terminologiju: Igor Fisković, "O ranokršćanskim spomenicima naronitanskog primorja", u: Izdanja HAD, sv. 5, Znanstveni skup "Dolina rijeke Neretve od prethistorije do ranog srednjeg vijeka", Metković, 1977., Split, 1980. 
ju, uz fotografiju kada su crkve konzervirane, a većinom su doneseni i sažeti podatci o arhitektonskoj skulpturi. Također autorica donosi povijesni pregled istraživanja uz bibliografski pregled.

Sve smo ove radove već citirali, a u nastavku izlaganja, ovisno o temi koju dotičemo, navest ćemo samo neophodne, ili izvore informacija koji prijašnjim pregledom nisu spomenuti.

Sagledavajući vrlo živi znanstveni interes za starokršćansku problematiku, očitovan i brojnim recentnim studijama izravno ili, po prirodi značenja ovoga prostora, s neizostavnim tematskim osvrtom vezanim za Mostar, neminovno postavljamo pitanje zašto je istraživanje starokršćanskoga horizonta ovoga područja ne samo u stagnaciji, nego je zapravo arheološka baština vrlo ozbiljno izložena očitovanoj destrukciji koja je u progresu.

Izneseni komentar osnovan je, kao što je rečeno, na publiciranim radovima. Reakcija stručnoga i javnoga mnijenja, kao kritika i prosvjed, iskazana je od Društva povjesničara umjetnosti Hercegovine u Mostaru, koje je organiziralo javnu tribinu kojom su izravno predočeni problemi zaštite arheoloških starokršćanskih lokaliteta. ${ }^{29} \mathrm{Ta}-$ kođer, ukazujemo na magistarski rad Marije Gavrilović "Područje današnjeg Mostara i okolice u rimsko doba". Radom su obuhvaćeni svi lokaliteti, njih 35, koji su zabilježeni u Arheološkom leksikonu i koje je autorica obišla tijekom ljeta 2018. godine. Ovaj rad je mjerodavan, recentni izvor informacija o navedenim lokalitetima uz predočene fotografije, uz nekoliko zračnih snimaka dronom..$^{30}$ Također, a iskazano je u ovome radu, čini nam se važnim skrenuti pozornost na primijećeno nestajanje nekih, čini se još samo u arheološkoj literaturi zabilježenih toponima, kao i gubitak "sjećanja" o arheološkim nalazima, što je vjerojatno produkt generacijskih promjena ili recentnih migracija. ${ }^{31}$ Napominjemo, ponukani primijećenim promjena-

29 Jasno je ukazano na neprihvatljivost odnosa prema arheološkoj starokršćanskoj baštini koji je očitovan njezinim uništavanjem (lokalitet Crkvina u Sutini), ili ugrožavanjem agresivnom stambenom izgradnjom (lokalitet Crkvine, Cim). Izvješće s javne rasprave publicirano je u biltenu DPUmH, https:// dpumh.files.wordpress.com/2016/05/bilten_1_16.pdf (13. 1. 2019.).

30 Marija Gavrilović, Područje današnjeg Mostara i okolice u rimsko doba, Univerzitet u Sarajevu, Filozofski fakultet, Katedra za arheologiju, Sarajevo, 2018. http://ff.unsa.ba/files/zavDipl/18_19/arh/Marija-Gavrilovic.pdf (13. 1. 2019.).

31 Isto, str. 25, bilj. 107, 108. 
Ivanka Ribarević-Nikolić - Mostar u svjetlu znanstvenoga interesa...

ma na arheološkim lokalitetima, iskazanim i u citiranom radu M. Gavrilović, da su kontakti s lokalnim pučanstvom, općenito informiranje o arheološkoj povijesti istraživanja i arheološkim nalazima, te uzajamna razmjena informacija neophodni dio zaštite spomenika. Uključivanja zainteresiranih volontera u programski koncipiranu suradnju, preventivni je dio zaštite kulturne baštine, osobito arheoloških lokaliteta. ${ }^{32}$

Dat ćemo sažet prikaz dosadašnjih arheoloških istraživanja i trenutačna stanja istraženosti ili očuvanosti starokršćanskih lokaliteta na području Mostara. Također, predlažemo okvirne smjernice mjera zaštite.

Cim, lokalitet Crkvine proglašen je nacionalnim spomenikom. Svojevremeno gradska uprava Mostara otkupila je privatno, kultivirano, zemljište da bi starokršćanski lokalitet bio istražen i konzerviran. Danas je lokalitet ugrožen okolnom privatnom izgradnjom. Vjerujemo da je otkup okolnoga zemljišta jedini način da se ovaj jedinstveni lokalitet od iznimne važnosti spasi i prezentira. Projektom kulturnoga menadžmenta, kojim bi trebalo predvidjeti i pristup lokalitetu, uložena sredstva zasigurno mogu doprinijeti višestrukoj dobiti široj i užoj društvenoj zajednici.

Žitomislići, lokalitet Crkvine (i nekropola stećaka) nacionalni je spomenik. Arhitektonski kompleks je istražen i konzerviran. Lokalitet je ugrožen nekontroliranim raslinjem. Smjerokazi ili turističke informacije na glavnom magistralnom putu nisu primjetni.

Sutina (Sv. Ivan?), arhitektonski ostatci starokršćanske crkve u cijelosti su uništeni. U zaleđu novoizgrađenoga prodajnog centra danas je deponija otpadnog materijala koji treba ukloniti u cilju zaštite okoliša i ekoloških mjera očuvanja obala Neretve, a ujedno i pregledati, jer moguće sadrži ostatke obrađenoga kamena s lokaliteta.

Potoci, lokalitet Grčine i cjelovit prostor naselja, potrebno je ponovo rekognoscirati. Ovaj važan lokalitet nikada nije u cijelosti sustavno istražen.

32 Stephen Doempke (ed.), The UNESCO World Heritage and the Role of the Civil Society, Proceedings of the International conference, World Heritage Watch, Bonn, 2015., http://openarchive.icomos.org/1692/ (10. 10. 2018.). Ukazujemo i na znanstveno koncipiran međunarodni projekt koji je pokrenula dr. Sarah Parcak, GlobalXplorer, koji je baziran na suradnji sa zainteresiranim volonterima, https://www.globalxplorer.org (13. 1. 2019.). 
Lokalitet Humilišani, u neposrednoj blizini Potoka, jest potvrđeni starokršćanski lokalitet, čija je pozicija poznata i zahtijeva sustavna arheološka istraživanja. Naglašavamo da arhitektonska skulptura, kao i provedena probna arheološka istraživanja potvrđuju postojanje arhitektonskih ostataka sakralnoga objekta.

Na položaju Kuti neophodna su zaštitna arheološka istraživanja površinskih ostataka arhitekture, kasnoantičkoga i starokršćanskoga sakralnog objekta (zdenac krstionice). Također postoje i naznake kontinuiteta uporabe ovoga mjesta u kasnom srednjem vijeku.

U Blagaju su recentno arheološki potvrđeni ostatci sakralnoga objekta malih dimenzija. Znatno ranije pronađeni imposti, na drugoj lokaciji u gradu, ukazuju na postojanje starokršćanskoga položaja koji nije potvrđen arheološkim istraživanjima.

Lokalitet Vrelo Vrba, u Donjim Gnojnicama, zahtijeva konzervatorski program zaštite kasnoantičkih reljefa, što uvjetuje i zaštitu objekta u koji su ugrađeni spoliji. Svakako je neophodno ponovno rekognosciranje terena, a ovisno o dobivenim rezultatima i program arheoloških istraživanja.

Istaknimo da sedam (i hipotetski osmi) starokršćanskih lokaliteta na širem području Mostara, nesumnjivo potvrđuju intenzitet gradnje i naseljenosti ovoga područja, akcentirano, kako možemo pretpostaviti, u 6. stoljeću. Srednjevjekovni nalazi, kao i prethodni kulturni slojevi nisu spomenuti u ovome osvrtu. Nalazimo da bi mikro topografska karta arheoloških nalazišta $s$ modernim naseljima i postojećim cestama, a uz naznaku pretpostavljenih rimskodobnih komunikacija ukazala na "zone" arheoloških potencijalnih nalazišta i usmjerila pozornost stručnih organizacija i civilnoga društva na izravnu suradnju.

\section{Umjesto zaključka}

Izraženi pozitivni znanstveni interes svekolike akademske zajednice potvrđuje važnost ovoga povijesnog razdoblja, što je osvjedočeno navedenim spomenicima arheološke baštine. Upravo stoga teško je objasniti nedostatak prisustva i prihvaćanja tih mjerodavnih mišljenja na svim razinama definiranja suvremenih smjernica razvoja današnjega Mostara.

Nakon ovoga osvrta, umjesto zaključka, a polazeći od jednostavne istine da "budućnost počinje danas, a ne sutra" želimo ukazati na 
Ivanka Ribarević-Nikolić - Mostar u svjetlu znanstvenoga interesa...

važnost svih arheoloških lokaliteta u suvremenome društvu i na važnost njihova očuvanja i istraživanja "danas". Arheologija je znanost koja na ostatcima materijalne kulture, koji mogu biti pronađeni u zemlji, sustavnim iskopavanjima određenom metodom, slučajnim nalazima u zemlji ili na površini zemlje, objašnjava i rekonstruira način života i kulture starih civilizacija cjelokupna čovječanstva. ${ }^{33}$ Upravo stoga, arheologija i arheološki lokaliteti imaju univerzalnu vrijednost spoznaje koja je doprinos sveopćem budućem prosperitetu. Citirajući odabrana i mjerodavna mišljenja iz svijeta znanosti i umjetnosti pokušat ćemo pojasniti izrečenu tvrdnju. Ukazat ćemo na samo neke od mogućih odgovora na (znanstveno-etičko i didaktičko) pitanje: Zašto su arheološki lokaliteti korak u budućnost, a ne povratak u prošlost?

Ovaj kratak osvrt, koji smo simbolički nazvali "arheološki manifesto", a koji je, kako smo naglasili, skup citiranih odabranih mišljenja, nema izravnoga dodira s tematikom prezentiranom u ovome članku. Želimo istaknuti univerzalno značenje vrijednosti svih arheoloških lokaliteta neovisno o povijesnom razdoblju u kojemu su nastali, stila, namjene, njihova kulturološkoga, društvenoga, religijskoga ili zemljovidnoga određenja. "Arheološki manifesto" i simbolički i izravno govori o izvornim i nepatvorenim vrijednostima svih arheoloških spomenika i svih arheoloških lokaliteta.

Arheološki manifesto. "(...) Spomenik predstavlja znak vremena u prostoru, a (...) prostor i vrijeme temeljne su kategorije postojanja i mišljenja." Mi smo danas u prostoru i vremenu zajedno sa spomenikom. U kojoj mjeri je spomenik sastavni dio naše svakodnevice, tolika je i naša potreba da ga prihvatimo kao vlastitu "duhovnu kategoriju što se samo temelji na konkretnom materijaliziranom djelu". ${ }^{34}$

33 Enciklopedijski članak: "Arheologija", on-line izdanje, u: Hrvatska enciklopedija Leksikografskog zavoda Miroslav Krleža, www.enciklopedija.hr (13. 5. 2019.)

34 Radovan Ivančević, "Sto godina trajanja: problem kontinuiteta, tradicije i negacije baštine", u: Peristil, 31-32, Zbornik radova za povijest umjetnosti, V. kongres Saveza društava povjesničara umjetnosti SFRJ, Zagreb, 1988./1989., str. 10-11. Ovaj citat preuzet je iz teksta napisana prije trideset godina. Isti ovaj citat rabili smo u jednom prethodnom osvrtu vezanom za tematiku stećaka. Citiramo ponovo ovu univerzalnu poruku uz preporuku studiranja cjelovita članka. Iznenađeni smo koliko je naslov ove studije i danas aktualan. 
Koji smo od spomenika odabrali kao našu "duhovnu kategoriju", odluka je i sloboda izbora svakoga od nas i nipošto nije vezana za bilo kakvo sugerirano mišljenje ili preporuku. Također naš izbor ne mora biti samo jedan ili samo jedna određena skupina spomenika. Slobodni smo slijediti svoj ukus, vjerovanje, povijest, znanost, ili bilo koju ili svaku od odrednica našega odabira.

Pokušat ćemo pojasniti višeznačnost razmišljanja o spomeniku kao univerzalnoj kategoriji genijalnosti i ljudske kreativnosti, umjetnosti i tehnologije, te spomeniku kao duhovnome odrazu bogatstva u poimanju vrijednosti ljepote, iskazanoj upravo u različitosti njezina viđenja.

Citirat ćemo, prema našem osobnom izboru, tekstove koje prezentiramo kao "arheološki manifesto" u doslovnome i prenesenome značenju njihove poruke.

Citat koji slijedi sažetak je opširnijega osvrta i potaknut je pozitivnim primjerom uspješne suradnje hrvatskih znanstvenika na međunarodnoj razini. Tematski je vezan za znanstvenu raspravu o evaluaciji konzervatorskih uvjeta neophodnih za izlaganje i posudbu, tj. međumuzejsku razmjenu ostataka ljudskih fosila na primjeru ljudskih ostataka neandertalca iz Krapine u Hrvatskoj. Cilj odabira ovoga citata jest ukazati na univerzalnost njegove poruke, bez akcentiranja specifične konzervatorske problematike i upravo stoga izabrali smo kao primjer neandertalca, "pračovjeka".

"(...) U vremenu kada globalizacija ide zajedno sa socijalnim podjelama i netolerancijom, ovakvi fosili [okamenjeni ostatci] imaju izvanrednu snagu podsjetiti nas na naše zajedničko podrijetlo, dok težimo ka novom identitetu u svijetu problematske složenosti i razlika. U ovoj ulozi njihovo značenje prelazi granice znanosti idući ka diplomatskom, pokrećući pitanja koja mogu rasvijetliti naše uzajamno stajalište i tako dati priliku za izuzetno značajnu financijsku potporu za znanstvene i muzejske projekte u zemlji njihova podrijetla. Ljudski fosili [okamenjeni ostatci] su rijetki i dragocjeni arhiv ljudskih predaka koji treba dijeliti. Da bismo ih zaštitili i konzervirali mi želimo izgraditi standarde njihovog očuvanja i prezentacije koja će omogućiti, a ne onemogućiti, pristup nekima od njih." ${ }^{35}$

35 Jill Cook - Clare Ward, "Conservation assessment of the Neanderthal human remains from Krapina, Croatia and its implications for the debate on the display and loan of human fossils", u: The British Museum Technical Research Bulletin, Volume 2, London, 2008., https://www.britishmuseum.org/pdf/ 
Nadalje, razmišljajući o vjerovanjima, simbolima, legendama i pričama koje su stvorene u vremenu svojega nastanka, zaključit ćemo da su one zajednički dio ljudske odlike, vjerojatno iste starosti kao i "pračovjek", neandertalac. Tako nastali, neki simboli postaju dio usmenoga predanja, ponekada pretočeni u "zadati" pisani kanon, postaju magično moćni materijalni znaci u formi nekoga od spomenika. Za svakoga od nas, svaki od tako nastalih simbola jest "spontani proizvod psihe, a svaki od njih u sebi nosi, i to neoštećenu začetnu snagu svojega izvora" u odrazu "junaka s tisuću lica", kako je to, znatno složenije i znanstveno, izrečeno u kapitalnom djelu Josepha Campbella. ${ }^{36}$ Upravo stoga i neumitno, ono što nazivamo prošlim vremenom dio je naše svakodnevice, sadašnjega vremena. Sa spomenikom smo povezani fizički u prostoru, a slobodom našega izbora duhovno, našim osjećanjima, mišljenjem ili vjerovanjem.

Na impresivan način Salvador Dali, čuveni slikar (1904. - 1989.), razmišljajući o vlastitom umjetničkom djelu govori o uzajamnom odnosu objekta, artefakta ili spomenika, i promatrača. Pišući 1959. godine o kolekciji nakita koju je slikar kreirao, a koja je izrađena u plemenitim metalima i dragom kamenu i izložena u njegovu muzeju u rodnom Figueresu, Dali ukazuje na osnovnu ideju svoje kreacije u kojoj se očituje uzajamno djelovanje "duha, materije, vremena i prostora". Nadalje, Dali kaže: "Bez publike, bez promatrača, ovaj nakit ne bi ispunio funkciju za koju je stvoren. Promatrač neminovno postaje umjetnik. Stoga vid, srce i um promatrača, s većim ili manjim razumijevanjem, sjedinjuju i prihvaćaju zamisli kreatora nakita - daju nakitu život." ${ }^{17}$

BMTRB\%202\%20Cook.pdf (27. 10. 2018.). Donosimo citat interpretiranoga teksta: "At a time when globalization goes hand in hand with social fragmentation and intolerance, such fossils have the extraordinary power to remind us of our common origins as we search for new identities in a world of complexity and difference. In this role their significance extends beyond science to the diplomatic, provoking questions that may enlighten our attitudes to one another and providing opportunities to raise crucial funding for scientific and museum projects in the country of origin. Human fossils are rare and precious archives of human ancestry that need to be shared. To protect and preserve them we need to build standards of care and presentation that will enable this, rather than restrict access to the few."

36 Joseph Campbell, Junak s tisuću lica, Jesenski i Turk, Zagreb, 2009., str. 16.

37 Salvador Dali, Jewels, The Collection of The Gala-Salvador Dali Theatre, Museum in Figueres, Spain, 2011., str. 13, 23. 
Nakon navedenih primjera, zasigurno, najvažnije je istaknuti edukacijsku ulogu koju imaju umjetnička djela, muzejski i arheološki spomenici. Djeca u kontaktu sa spomenikom uče gledati, vidjeti, razmišljati i zaključivati.

Na jednom arheološkom lokalitetu, poput Mogorjela, ili, kao primjer, nekoga starokršćanskog sakralnog objekta čiji su ostatci konzervirani, djeca uče orijentirati se u prostoru, zamisliti koliko je prostorija taj prostor mogao imati, razlikujući vanjske i unutarnje zidove, kakva su oblika bile te prostorije, jer postoje polukružni i pravokutni oblici, uočavaju metričke vrijednosti, zaključujući da postoje mali i veliki prostori, jedna ili više povezanih prostorija, razvijaju kreativnost i imaginaciju, te kao pozitivni zaključak, izgrađuju sposobnost apstraktnoga mišljenja toliko važnog za razumijevanje prirodnih znanosti. $^{38}$

Ako smo dovoljno sretni da imamo arheološke lokalitete, i ako educiramo djecu na ovakav kreativan didaktički način u kontaktu sa spomenikom i ujedno u kontaktu s prirodom, nisu li onda arheološki lokaliteti korak u budućnost?!

Da bismo potvrdili sva iznesena viđenja, za početak treba živjeti u okružju koja ima na primjer jedan rimskodobni arheološki lokalitet. Zatim treba znati nešto više o tom lokalitetu, te stoga on treba biti znanstveno istražen. Da bi bio viđen, a ne samo prezentiran na papiru stručnoga malotiražnog časopisa, treba biti konzerviran. Da bi opstao u prostoru povijesnoga vremena, što je isti prostor našega sadašnjeg vremena, treba biti održavan. I kao najvažnije, trebamo imati spoznaju da taj arheološki lokalitet postoji, da bismo ga mogli posjetiti, te da bismo i sami bili oplemenjeni vlastitom spoznajom da svi mi jesmo "umjetnici" i da bismo dali spomeniku "život", kako to kaže Salvador Dali.

Da sve navedeno nije produkt teoretskoga razmišljanja arheologa, povjesničara umjetnosti, antropologa, pedagoga, metodičara ili specijalista kognitivne psihologije, nije teško provjeriti.

38 Prezentirani način samo je idejni primjer koncepta edukacije. Interaktivna metoda učenja dio je pedagoške ponude specijaliziranih ustanova kulture. Pitanje je koliko je to dio regularnoga edukacijskog sustava. 


\section{Mostar in the light of scientific interest of the early Christian archaeology}

\section{Summary}

Attention is given to the relief decorated late antique stone fragments which were built as spolia in the facade of a very interesting architectural construction with Islamic stylistic features of the spring "Vrelo Vrba" located in Donje Gnojnice, south of Mostar. Since we often find them as a decoration of the early Christian architectural sculpture, motifs of branches and vine leaves with bunches, hypothetically, point out the existence of the early Christian object in this place. At the same time, it is known that the motif of vine with bunches of grapes is not exclusively connected to sacral architecture in terms of iconography, therefore possibility of different provenance of this relief may not be excluded (Figure 1-3). Conservation works are necessary to be done for both late antique reliefs and the object "Vrelo Vrba". This space has not been archaeologically explored. The site was registered at the end of the $19^{\text {th }}$ century.

The article also points out the level of exploration and preservation of the seven so far known early Christian sites in the area of the present Municipality of Mostar. Those are Cim, Sutina, Potoci, Humilisani, Kuti, in the north part of the city and Zitomislici and Blagaj in the south part.

There are three important early Christian sites where remains of architecture were confirmed by archaeological research method. Those are Cim, Zitomislici and Sutina (Figure 4, 5, 6). The archaeological site in Sutina was completely destroyed together with remains of the early Christian church architecture (Figure 6). The author gives a critical overview of the protection level of two conserved early Christian architectural sacral complexes, the one in Cim and the other in Zitomislici. Early Christian archaeological site in Cim (Figure 4) was endangered by aggressive housing construction. Early Christian architectural complex in 
Zitomislici (Figure 5) has not been adequately presented and it seems that nobody takes care of the site conservation.

The article especially emphasizes necessity of the systematic archaeological research at some sites where the existence of the early Christian sacral architecture was confirmed, such as $\mathrm{Hu}-$ milisani site (Figure 7, 8).

At the end of the article the author pointed out the value and significance of all the archaeological sites in general. Selected thoughts of scientists and artists were cited and consolidated as a symbolic message which we called "archaeological manifesto": Archaeological sites are steps into the future and not return to the past.

Keywords: early Christian archaeology; Mostar; spolia; Donje Gnojnice; archaeological manifesto. 
Ivanka Ribarević-Nikolić - Mostar u svjetlu znanstvenoga interesa...

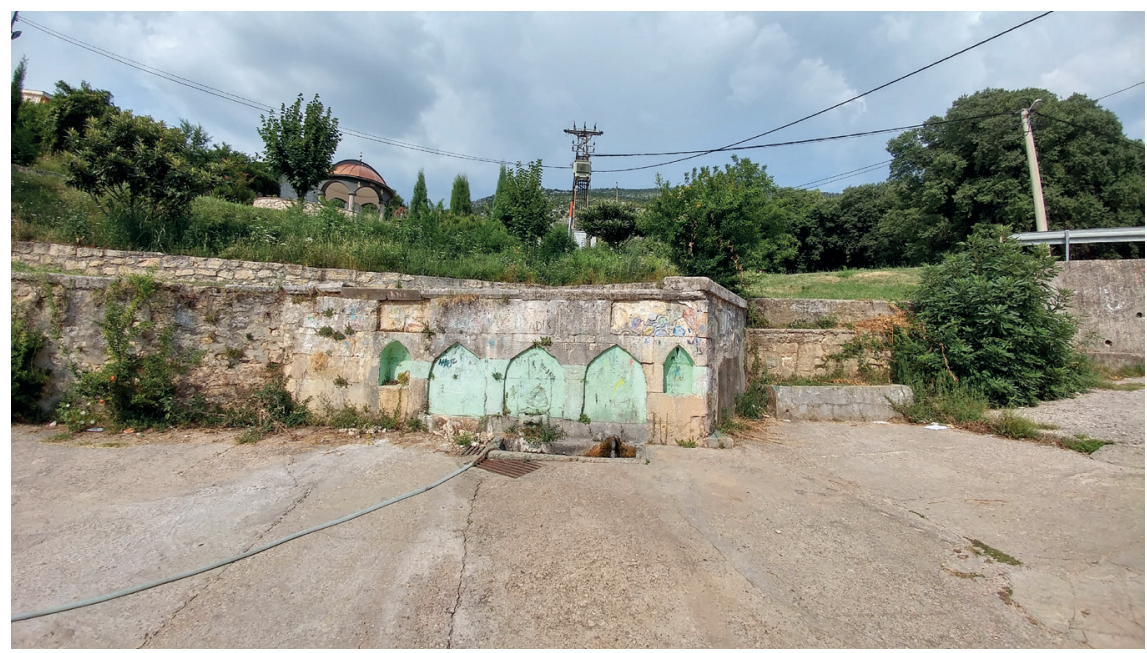

S1. 1. Vrelo Vrba u Donjim Gnojnicama kod Mostara (foto: R. Nikolić, 8. 8. 2018.)

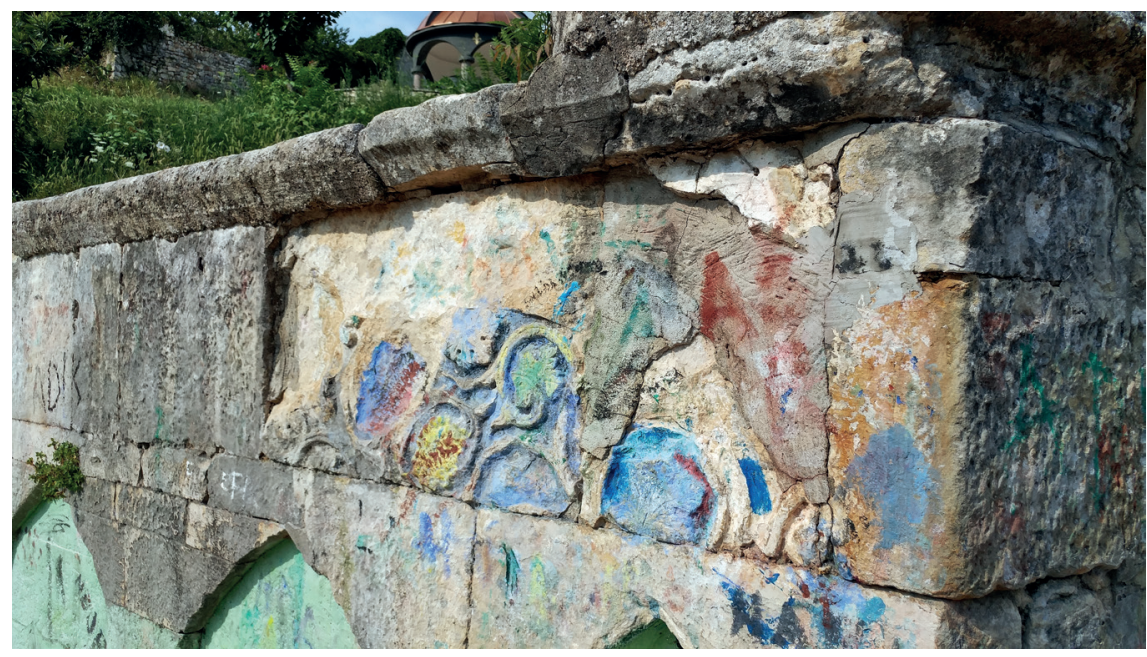

Sl. 2. Vrelo Vrba u Donjim Gnojnicama kod Mostara, reljef s motivom vinove loze ugrađen u pročelje objekta (foto: R. Nikolić, 8. 8. 2018.) 
Hercegovina - 5 - 2019., str. 7-39

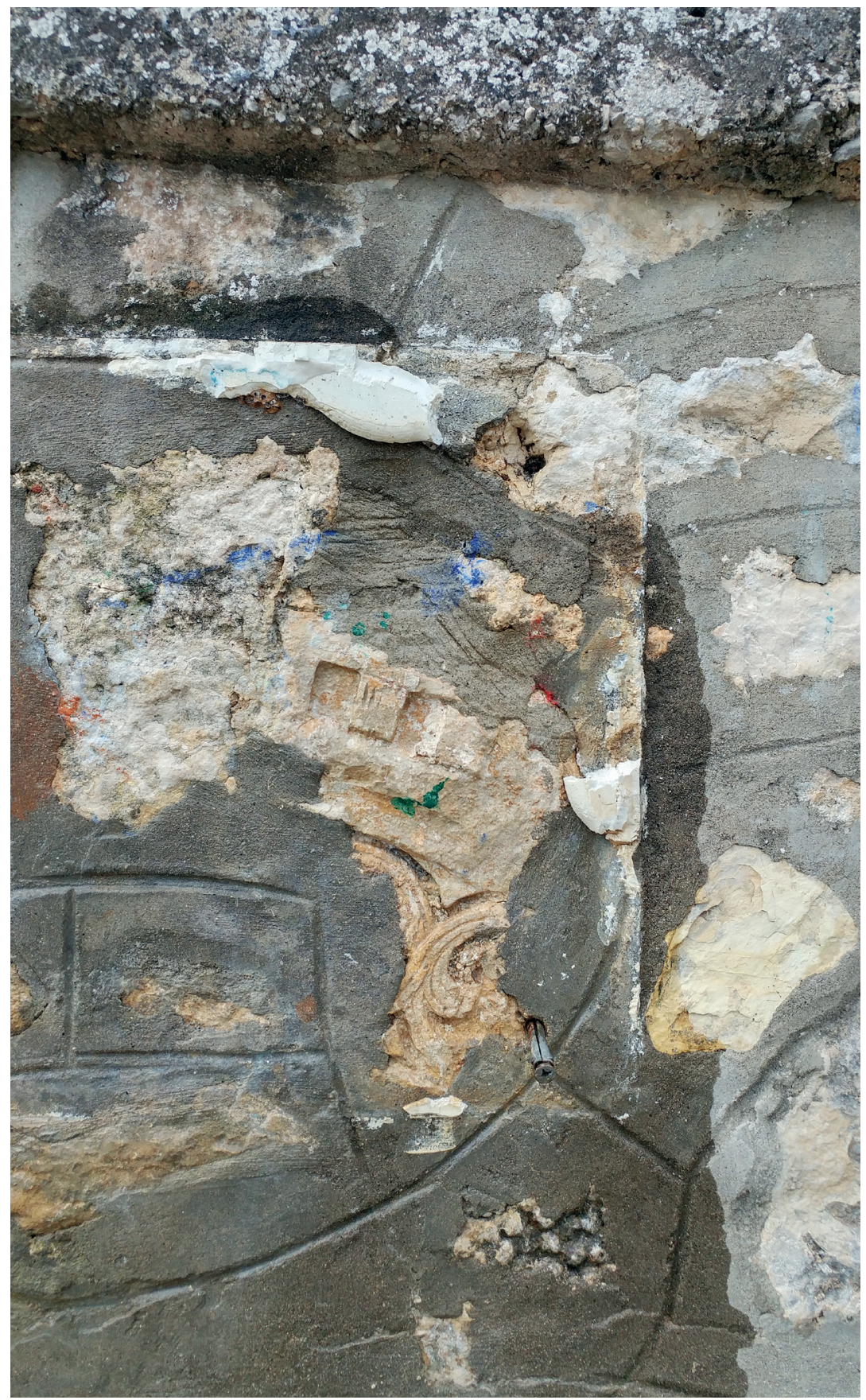

S1. 3a. Vrelo Vrba u Donjim Gnojnicama kod Mostara, fragmenti reljefa upotrijebljeni kao građevni materijal na bočnoj strani objekta (foto: $R$. Nikolić, 8. 8. 2018.) 
Ivanka Ribarević-Nikolić - Mostar u svjetlu znanstvenoga interesa...

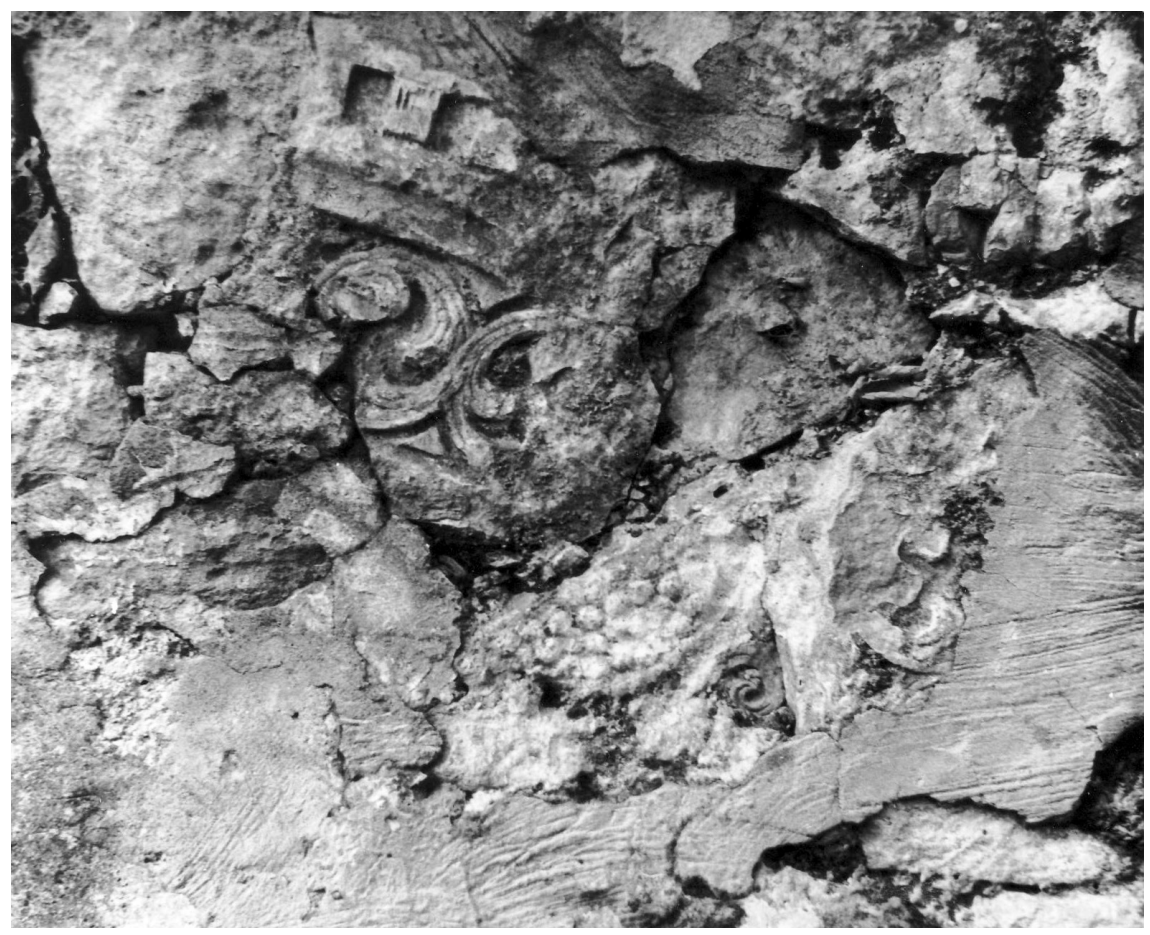

Sl. 3b. Vrelo Vrba u Donjim Gnojnicama kod Mostara, fragmenti reljefa upotrijebljeni kao građevni materijal na bočnoj strani objekta, Izvor: Regionalni zavod za zaštitu spomenika kulture i prirode u Mostaru (foto: autor nepoznat, prije 1990.) 


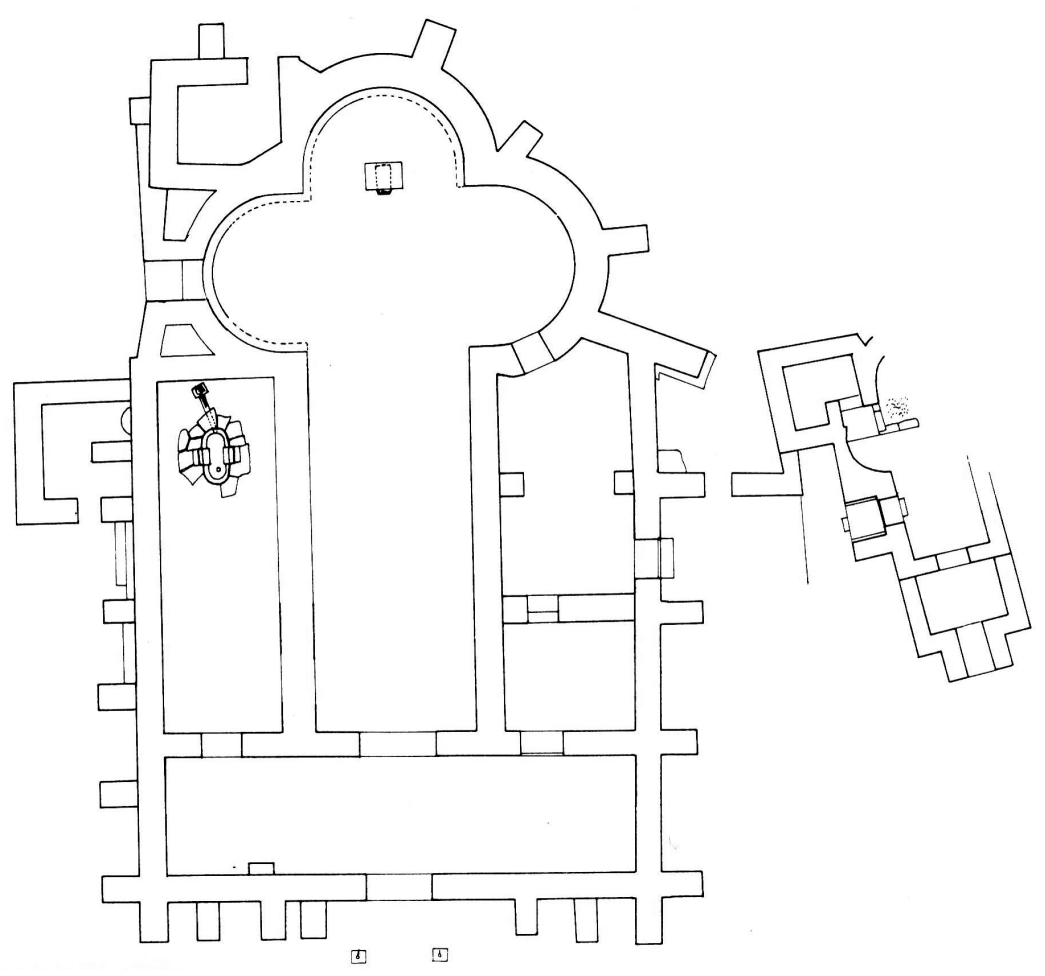

Sl. 4. Cim, Mostar, Plan starokršćanske arhitektonske cjeline (crkva i memorija) Prema: Tomislav AnĐElić, "Kasnoantička bazilika u Cimu kod Mostara", u: Glasnik Zemaljskog muzeja, 29, (1974.), Sarajevo, 1976., str. 179-244. 
Ivanka Ribarević-Nikolić - Mostar u svjetlu znanstvenoga interesa...
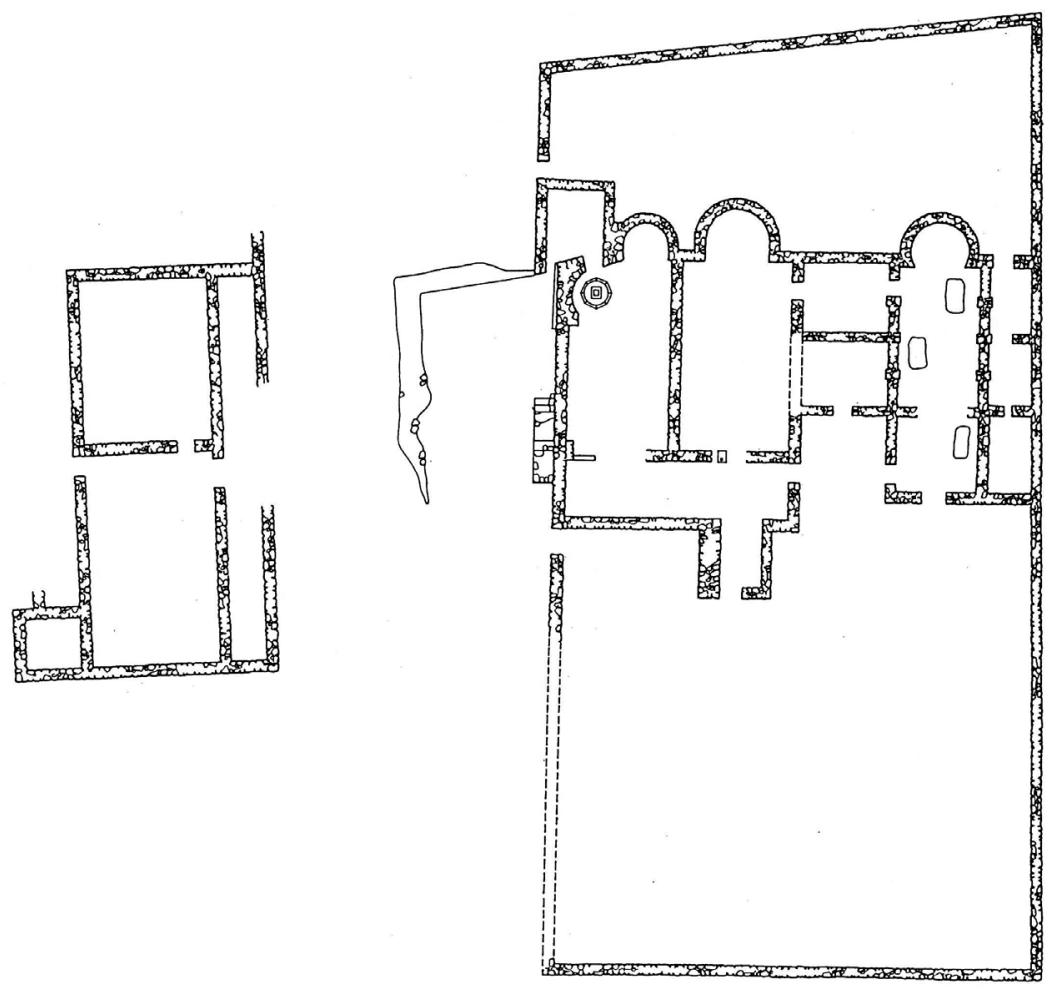

Sl. 5. Žitomislići kod Mostara, Plan starokršćanske arhitektonske cjeline Prema: ToMislav ANĐELIć, "Kasnoantička dvojna bazilika (basilica geminata) u Žitomislićima kod Mostara", u: Glasnik Zemaljskog muzeja, 32 (1977.), Sarajevo, 1978., str. 293-330. 


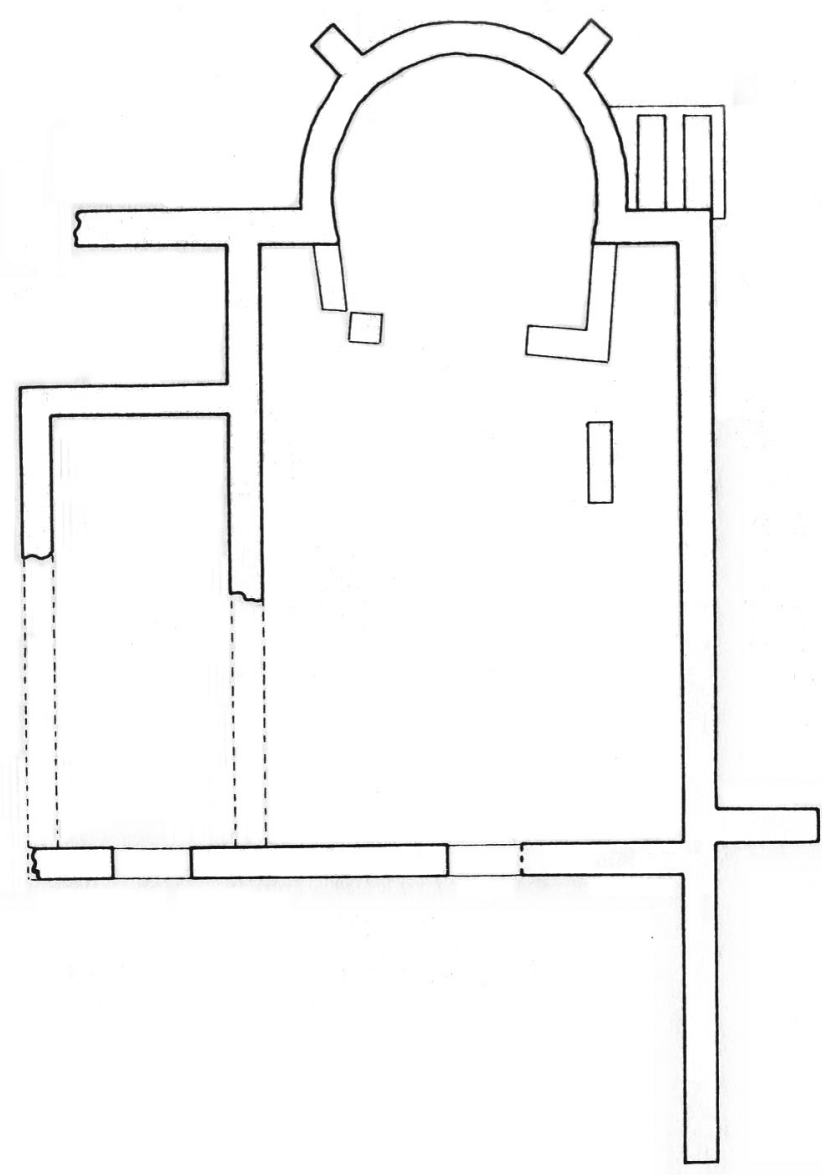

S1. 6. Sutina, Mostar, Plan starokršćanske crkve Prema: Vukosava Atanacković-SALČić, "Nove ranokršćanske crkve na području Mostara", u: Hercegovina, 3(11), Mostar, 1997., str. 23-30. 


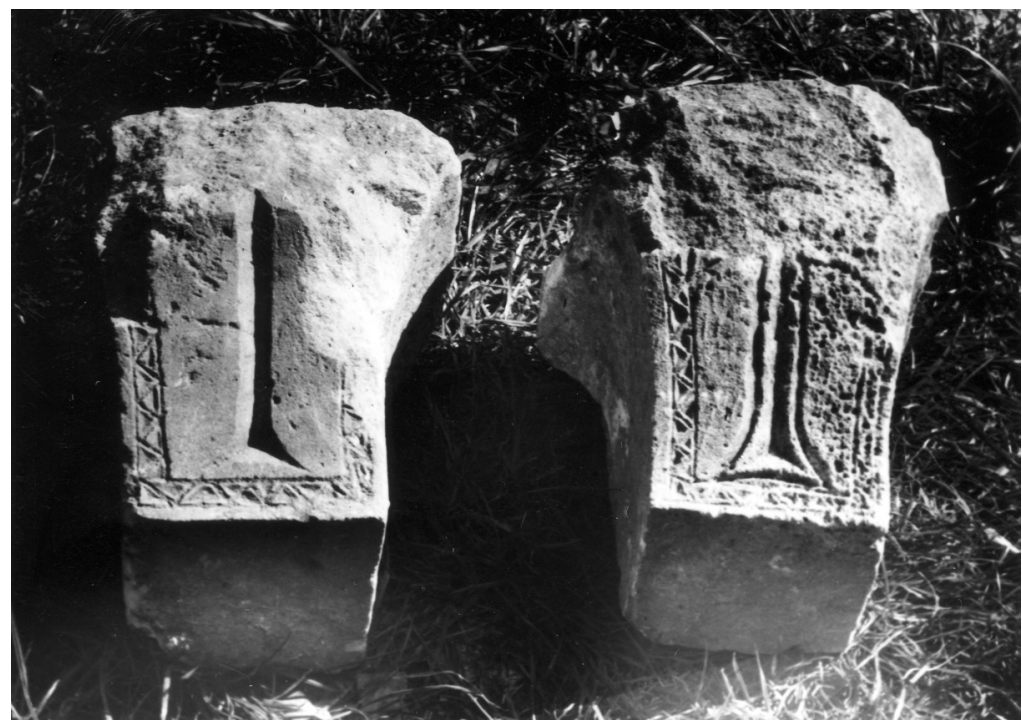

Sl. 7. Humilišani kod Mostara. Imposti pronađeni tijekom probnih arheoloških istraživanja V. Atanacković-Salčić, Izvor: Regionalni zavod za zaštitu spomenika kulture i prirode u Mostaru (foto: Ćiro Raič)

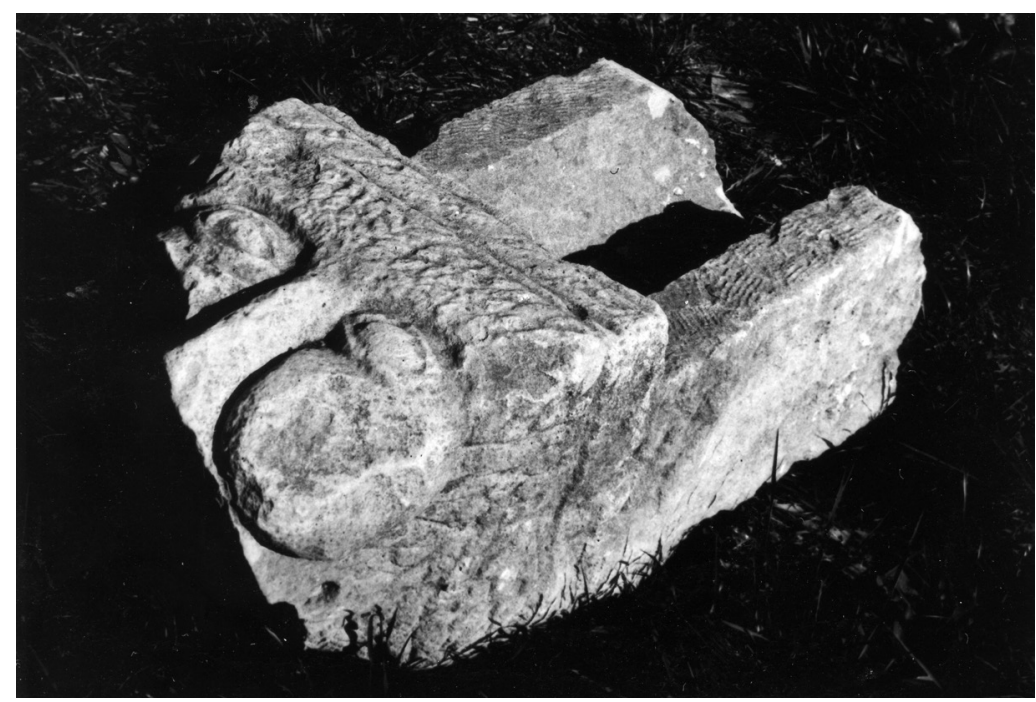

Sl. 8. Humilišani kod Mostara. Specifični arhitektonski element ("kanal" za vodu) s motivom lavlje glave, pronađen tijekom probnih arheoloških istraživanja V. Atanacković-Salčić, Izvor: Regionalni zavod za zaštitu spomenika kulture i prirode u Mostaru, (foto: Ćiro Raič) 


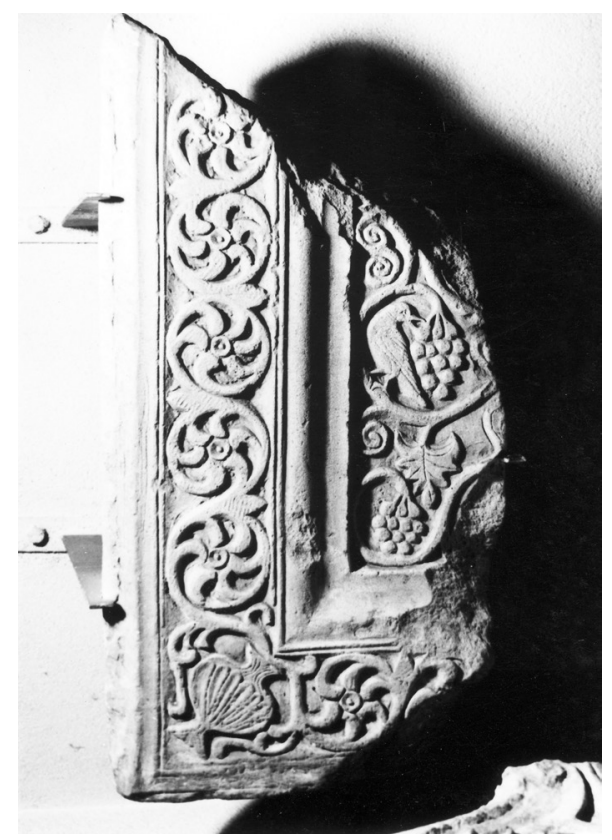

S1. 9. Potoci kod Mostara, Starokršćanski reljef Zemaljski muzej u Sarajevu, inv. br. 465, (Ljubaznošću Muzeja, foto: Ćiro Raič, 1991.)
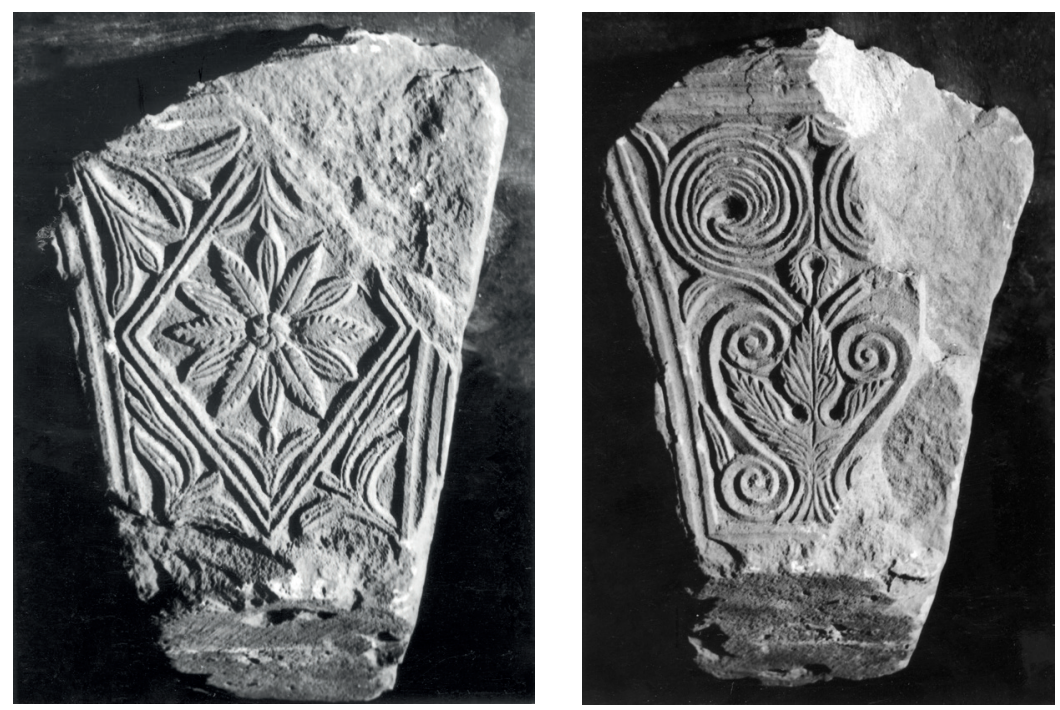

Sl. 10a, 10b, Blagaj kod Mostara, Reljefno ukrašene strane imposta, Zemaljski muzej u Sarajevu, inv. br. 438, (Ljubaznošću Muzeja, foto: Ćiro Raič, 1991.) 
Ivanka Ribarević-Nikolić - Mostar u svjetlu znanstvenoga interesa...

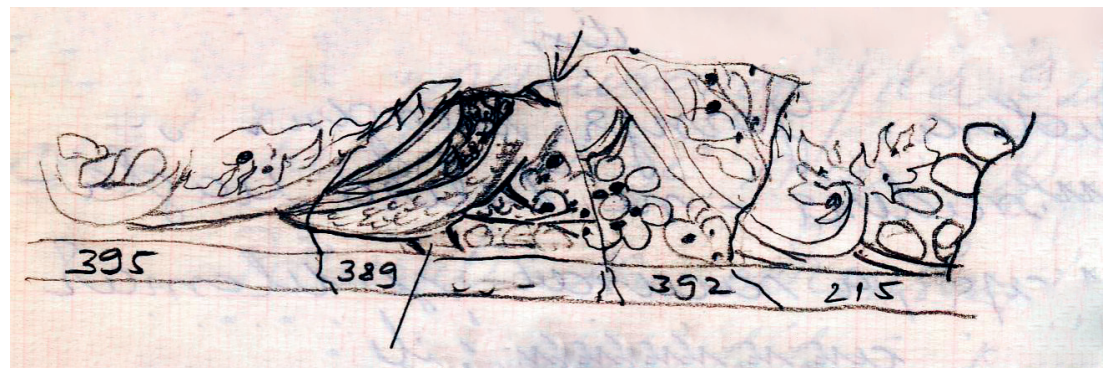

S1. 11a. Radna skica uklopljenih ulomaka reljefne ploče iz Cima (inv. br. 395, 389, 392, 215) Muzej Hercegovine u Mostaru (I.R.N., 1. 10. 1990., uza zahvalu za mogućnost rada u depou Muzeja)

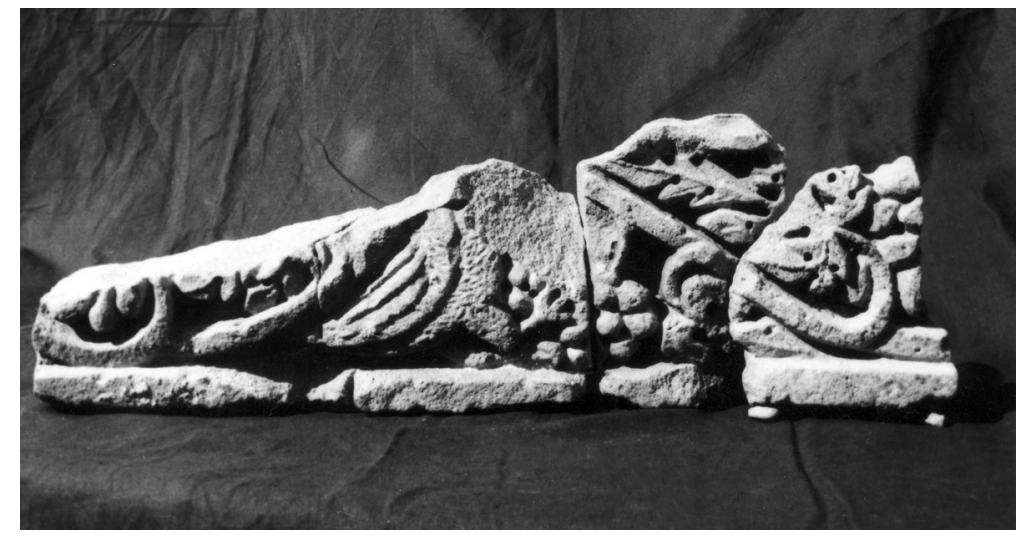

S1. 11b. Cim, dijelovi reljefne ploče, Muzej Hercegovine u Mostaru, inv. br. 395, 389, 392, 215

(Ljubaznošću Muzeja, foto: Ćiro Raič, 1990.) 


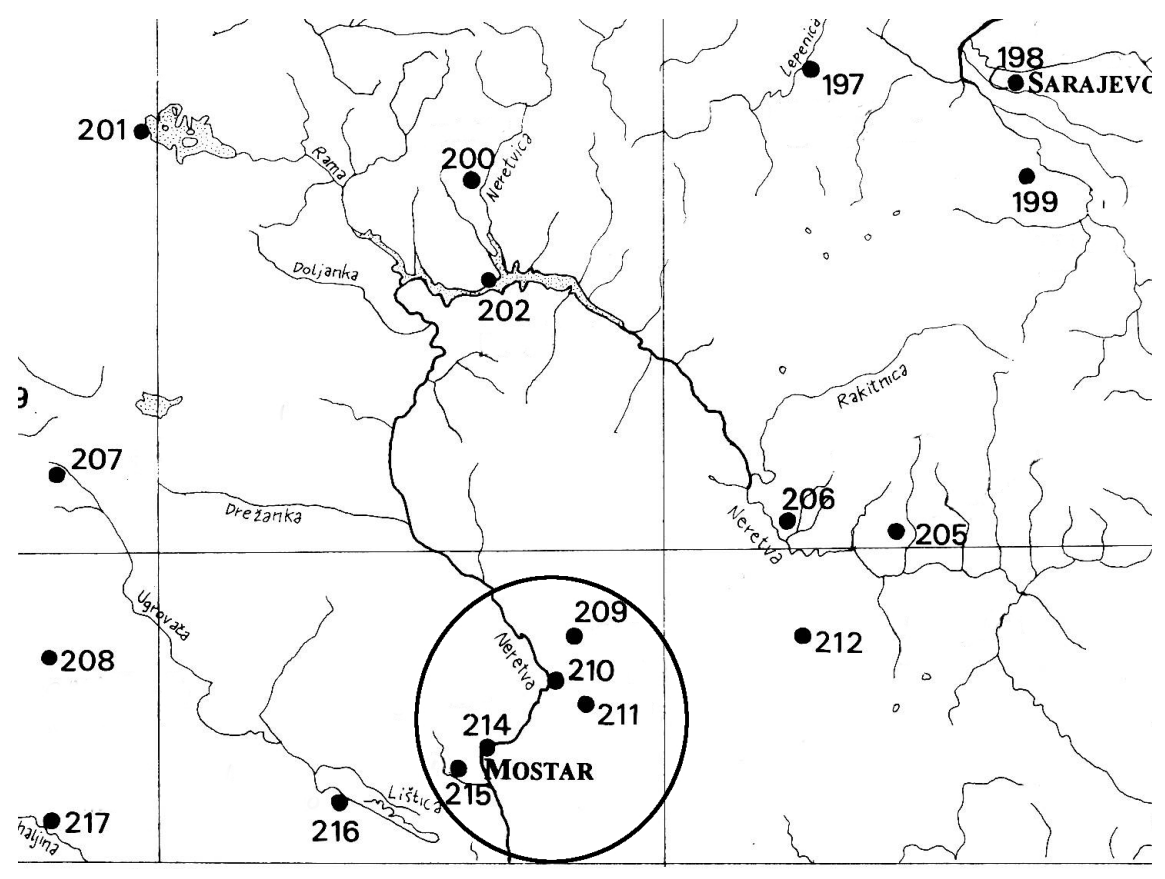

Karta 1 - Starokršćanski lokaliteti na području grada i sjeverno od Mostara: 215 Cim, 214 - Sutina, 211 - Potoci, 210 - Kuti, 209 - Humilišani Prema: Pascale Chevalier, Salona II, L'architecture paléochrétienne de la province romaine de Dalmatie (IV-VII s.), En dehors de la capitale, Salona, Tome 1 - Catalogue, Rome - Split, 1995., Carte V: Nord-Est de la Bosnie-Herzegivine, Travnik - Mostar (obrada I.R.N., prikazan je detalj karte i krugom istaknuti lokaliteti) 